\title{
Methodical approaches to creation of standard samples of soil material with known content of microelements-metals
}

\section{Sementsova K.}

NSC "A.N. Sokolovsky Institute of soil science and agrochemistry», Chaikovska Str., 4, Kharkiv, 61024, Ukraine; e-mail: Ekaterinasemenc@gmail.com

The purpose. To analyze modern requirements to soil material for creation of standard samples of soil with the known content of microelements-metals, to establish features of procedure of manufacturing samples and to offer possible ways of their realization. Methods. Theoretical and comparative-analytical methods are used for substantiation of methodical approaches to preparation and certification of material of standard samples of soil structure, laboratory - for working out procedure of preparation of soil material for creation of standard samples of soil as to content of microelements-metals, methods of mathematical statistics - for processing experimental data. Results. Methodical approaches are analyzed to metrologically correct procedure of manufacturing soil material with the known content of microelementsmetals (spiked samples). Owing to impossibility to provide the accepted accuracy and reliability of results of measurements of the content of mobile connections of microelements in soils with their background content, necessity of application of the method of additives with obligatory maintenance of commutability of material is proved. Conclusions. By development and realization of procedure of manufacturing standard samples certified on mass fraction of microelements, it is necessary to consider extremely high heterogeneity of soil material, usually low mass fraction of microelements-metals and other features which can complicate establishment of certified values of their mass fractions. Metrologically correct procedure of preparation of soil material should consider and minimize reasons of occurrence of errors of results of measurements so that standard samples to the greatest degree meet special-purpose designation.

Key words: standard sample, microelements-metals, procedure of preparation of soil material.

DOI: https://doi.org/10.31073/agrovisnyk201903-11

Introduction. An integral part of the quality assurance of analytical work is the use of standard samples (SC) of the composition of substances. According to [1], a standard sample of the composition or properties of substances (material) is a means of measuring in the form of an appropriate amount of substance or material, intended to reproduce and store the sizes of quantities that characterize the composition or properties of this substance (material), the values of which are established as a result of the metrological attestation, and which is used to transmit the unit size during calibration, calibration, certification of measurement techniques and approved by the current order as a standard sample.

Soil is a complex subject of research. This is due to the peculiarities of its physical and chemical properties and the content of trace elements. When determining the available forms of trace elements in soils, it is necessary to consider that their content in soils is rather small. The quality of the soil analysis results is characterized by the accuracy of the results obtained.

The basic requirements for the soil material intended for the preparation of SC are the similarity of its micromorphological (soil matrix - a framework of soil consisting of solid particles (or their micro aggregates) with pores between them) and agrochemical properties to these properties of the investigated soil samples. The similarity of the micromorphological structure is a prerequisite for providing the possibility of qualitative measurement and minimizing the negative impact on the measurement results of unmatched matrix effects. It should be noted that in the national soil science, the concept of "matrix of soil" is practically not used [2]. 
The main purpose of the SC soil, certified for the content of metal trace elements, is to ensure the accuracy, reliability and traceability of the results of measuring the content of mobile compounds of trace elements in agricultural soils.

Soil quality SC requirements, according to which the suitability of soil material for SC production is further assessed, is formed by finding a compromise between the possibilities of the manufacturer of SC to provide certain values of the metrological characteristics of this measuring instrument and the financial costs for its development and user needs, that is, based on considerations of practical expediency.

The first stage in the development of the $\mathrm{SC}$ is the choice of suitable soil material.

The object of the study is a soil material for the production of SC on the soil, certified for the content of metal trace elements.

Objectives of the work - to analyze the main stages of the procedure for the production of SC of soil with known content of metal trace elements.

Research methods: DSTU ISO 10390-2001 Ground quality. Determination of pH [3]; DSTU4730: 2007 Quality of soil. Determination of granulometric composition by the pipette method for modification AN Kaczynski [4]; DSTU 4770.1,2,4-6: 2007 Quality of soil. Determination of the content of mobile compounds of manganese (zinc, iron, cobalt, copper) in soil in a buffer ammonium acetate extraction with $\mathrm{pH} 4.8$ by atomic absorption spectrophotometry [5]; MBB 31-497058-016-2003 «Soils. Determination of the content of hard-fixed forms of heavy metals ( $\mathrm{Co}, \mathrm{Cu}, \mathrm{Cd}, \mathrm{Ni}, \mathrm{Pb}, \mathrm{Zn}, \mathrm{Mn}, \mathrm{Fe}$ ) in soils in hydrochloric $(\mathrm{HCl})$ extracts by an atomic absorption spectrophotometer $»$.

Discussion of research results. In assessing the procedures for the preparation of a material SC certified for the content of trace elements, the methods of developing standard samples, described in accessible sources of information, were analyzed.

They can be divided into the following types:

- SC, which are developed on the basis of natural materials;

- SC, which are developed from anthropogenically modified natural materials, certified by quality indicators and toxicological contamination [6].

- artificially creating the SC.

Testing agrochemical laboratories are interested in the fact that the content of trace elements in standard soil samples, which they use in routine practice, was as close as possible to their content in soil samples, the composition of which is determined. The content of trace elements in unpolluted (background) soils, the samples of which are usually analyzed to determine the needs of crops in microelement nutrition and microfertility rates, in most cases, is quite low, at the limit of the sensitivity of the devices used during the measurements. The error (or uncertainty) of the measurement results can be so great that the expediency of such measurements in general is lost. For this reason, in order to increase the accuracy of the results of measurements of the content of mobile compounds, of trace elements in soils use standard samples containing these elements, somewhat higher than natural ones. When interpreting measurement results, this feature is taken into account.

It was decided to evaluate the suitability of the surface layer $(0-20 \mathrm{~cm})$ for soil that could have been technogenically contaminated (this assumption was made on the basis of previous studies) for the preparation of the SC material. The ground material (typical black currant) was selected at a distance of 10-15 m and 100-120 m from the M-03 highway (on Slavyansk (Donetsk region), Debaltsevo, Lugansk, Rostov-on-Don) to the northwest 2, $4 \mathrm{~km}$ from Chuguev city. It was expected that the content of mobile compounds of trace elements in soil material, selected at a distance of 10-15 m from the highway, would be higher than the background, and in the selected distance of $100-120 \mathrm{~m}$ - correspond to the background value.

According to the results of measurements of the content of mobile compounds of trace elements in a typical black earth material (Table 1), their content practically does not differ from the background. In addition, the presence of carbonates in the soil material made it impossible to determine the content of 
trace elements that were removed by a single-hydrochloric acid solution, as envisaged by the research program.

Table 1 - General characteristics of soil material selected at a distance of $10-15 \mathrm{~m}$ from the route and material selected at a distance of 100-120 m

\begin{tabular}{|c|c|c|c|}
\hline Types of analyzes & Indexes & $10-15 \mathrm{~m}$ & $100-120 \mathrm{~m}$ \\
\hline \multirow{4}{*}{$\begin{array}{c}\text { The content of mobile } \\
\text { compounds of trace } \\
\text { elements in a buffer extract } \\
\text { [6], mg/kg }\end{array}$} & $\mathrm{Co}$ & 0,21 & 0,18 \\
\cline { 2 - 4 } & $\mathrm{Cu}$ & 0,60 & 0,18 \\
\cline { 2 - 4 } & $\mathrm{Cr}$ & 0,17 & 0,15 \\
\cline { 2 - 4 } & $\mathrm{Fe}$ & 1,20 & 1,60 \\
\cline { 2 - 4 } & $\mathrm{Pb}$ & 0,31 & 0,85 \\
\cline { 2 - 4 } & $\mathrm{Mn}$ & 16,40 & 19,90 \\
\cline { 2 - 4 } & $\mathrm{Zn}$ & 0,95 & 0,42 \\
\hline Humidity of soil,\% HB & $\mathrm{Co}$ & 0,21 & 25,18 \\
\hline pH & & 24,47 & 7,76 \\
\hline \multirow{3}{*}{$\begin{array}{c}\text { Content } \\
\text { fractions, \% }\end{array}$} & $1-0,25 \mathrm{~mm}$ & 0,78 & 0,80 \\
\cline { 2 - 4 } & $0,25-0,05 \mathrm{~mm}$ & 3,74 & 3,92 \\
\cline { 2 - 4 } & $0,05-0,01 \mathrm{~mm}$ & 27,20 & 25,17 \\
\cline { 2 - 4 } & $0,01-0,005 \mathrm{~mm}$ & 11,82 & 12,77 \\
\cline { 2 - 4 } & $0,005-0,001 \mathrm{~mm}$ & 14,31 & 12,35 \\
\cline { 2 - 4 } & $<0,001 \mathrm{~mm}$ & 40,28 & 42,02 \\
\hline
\end{tabular}

In this regard, the selected soil material was found unsuitable for the purpose of the study and evaluated the feasibility of the use of ground material of black soil typical, selected from one control sites of the Slobozhansky experimental field of the NSC "IGA named after O.N. Sokolovsky" (from the village of Research, Chuguevsky district, Kharkiv region). Such a choice is due to the fact that the typical lowhumus hard-boiled black earth is well-studied here, the history of each area is documented, it can be guaranteed that in the control sites of experiments that are conducted here, for several decades, mineral and organic fertilizers were not introduced, and due to the annual plowing the soil is mixed to some extent (which can improve material homogeneity). For this reason, and given that potential consumers are interested in SC arable soil (most often in arable soils, agrochemical indicators are measured), a material from an arable soil layer of $0-30 \mathrm{~cm}$ is selected.

The general characteristics of the selected soil material are given in Table 2.

Table 2 - General characteristics of chernozem material typical of low-humus heavy-gravel

\begin{tabular}{|c|c|c|}
\hline Types of analyzes & Indexes & Sample of soil \\
\hline Humidity of soil, \% HB & & 27,11 \\
\hline $\mathrm{pH}$ & & 7,30 \\
\hline \multirow{3}{*}{ Content of granulometric fractions, $\%$} & $1-0,25 \mathrm{~mm}$ & 0,60 \\
\cline { 2 - 3 } & $0,25-0,05 \mathrm{~mm}$ & 1,77 \\
\cline { 2 - 3 } & $0,05-0,01 \mathrm{~mm}$ & 33,44 \\
\cline { 2 - 3 } & $0,01-0,005 \mathrm{~mm}$ & 11,72 \\
\cline { 2 - 3 } & $0,005-0,001 \mathrm{~mm}$ & 10,58 \\
\cline { 2 - 3 } & $<0,001 \mathrm{~mm}$ & 41,99 \\
\hline Total content of humus by Thurin, C. & & 3,15 \\
\hline
\end{tabular}

It was also determined the content in the soil of mobile compounds of trace elements. During the measurements a standard sample of the company SACHvS-05/2 (SC black earth extracted of medium soda) was used. 
Table 3 - The content of mobile compounds of trace elements in soil material

\begin{tabular}{|c|c|c|c|c|c|c|}
\hline \multirow{3}{*}{ Elements } & \multirow{2}{*}{$\begin{array}{l}\text { Background } \\
\text { content }\end{array}$} & \multirow{2}{*}{$\begin{array}{l}\text { The content } \\
\text { of mobile } \\
\text { compounds } \\
\text { of trace } \\
\text { elements in } \\
\text { a buffer } \\
\text { extract } \\
\text { pH } 4,8\end{array}$} & \multirow{2}{*}{$\begin{array}{l}\text { The content of } \\
\text { tightly fixed forms } \\
\text { of elements in the } \\
\text { hydrochloric } \\
\text { extract }\end{array}$} & \multicolumn{3}{|c|}{ SC (SACHvS- 05/2) [6] } \\
\hline & & & & SC & $\begin{array}{l}\text { Valid } \\
\text { values of } \\
\text { SC }\end{array}$ & Divergency \\
\hline & \multicolumn{6}{|c|}{$\mathrm{mg} / \mathrm{kg}$} \\
\hline $\mathrm{Cu}$ & 31,40 & 0,21 & 3,61 & 0,09 & 0,08 & $0,05-0,11$ \\
\hline Co & 18,00 & 0,35 & 1,16 & 0,13 & 0,11 & $0,08-0,14$ \\
\hline $\mathrm{Mn}$ & 754,00 & 1,04 & 110,6 & 99,35 & 15,70 & $12,54-18,8$ \\
\hline $\mathrm{Zn}$ & 57,00 & 0,23 & 4,34 & 0,11 & 0,44 & $0,22-0,65$ \\
\hline
\end{tabular}

Since it was not possible to select the soil material containing the movable compounds of ME metals, which would exceed the background level, it was decided to increase the content of ME in the soil material artificially, adding metal salt solutions ("by the method of additives"). Such artificially manufactured samples of materials with known content of analytes in international practice are called spiked samples and widely used in the practice of measuring laboratories [6].

The use of such samples allows you to determine the concentration of trace elements metals without additional concentration, which reduces the measurement error and allows you to work with small stresses.

In this case, it is necessary to ensure the implementation of a metrologically correct procedure for the preparation of soil SC material, namely its commutability (commutability) [6]. Commability of the material - this property of the material, which ensures the accuracy of the results at any stage of the study.

One of the methods for implementing the additive method for soil material is "initial wetting" [7], which is that the salts of metal trace elements are dissolved in the required amount of solvent sufficient to completely wet the surface of the soil material.

We have implemented two procedures for the creation of soil material with known content of metals trace elements:

- a series of samples weighing $2 \mathrm{~kg}$ each with a known content of metal trace elements (the quantity is a multiple background content of $\mathrm{Cu}, \mathrm{Zn}, \mathrm{Mn}, \mathrm{Co}$ ), which compacted on the soil moisture content of $60 \%$ of HB (six times);

- sample with a known content of microelements-metals weighing $25 \mathrm{~kg}$ (the amount of salts of trace elements in the soil sample is 1.5 gross $\mathrm{Cu}, \mathrm{Zn}, \mathrm{Mn}, \mathrm{Co}$ ).

A series of molar solutions (6 copies) with a known content of elements was made during the preparation of samples by composting method before the addition of metal trace elements (in the form of a solution of nitrates). Scheme of experiment is shown in Table. 4

Table 4 - Scheme of laboratory test for the production of samples with known content of metal trace elements (the quantity is multiplicity of background content)

\begin{tabular}{|c|c|c|}
\hline № samples & Reiteration & $\begin{array}{c}\text { The amount of micronutrients added, the share of } \\
\text { the background total content }\end{array}$ \\
\hline 1 & 6 & 0 \\
\hline 2 & 6 & 0,5 \\
\hline 3 & 6 & 1,0 \\
\hline 4 & 6 & 1,5 \\
\hline 5 & 6 & 2,0 \\
\hline 6 & 6 & 2,5 \\
\hline
\end{tabular}


After the first, third and sixth months of composting, samples were taken. Approximately $100 \mathrm{~g}$ of soil is selected from each experiment. After that, the contents of the moving forms of trace elements are determined on the ground.

Table 5 shows the correlation coefficients between the number of trace elements metals extracted by hydrochloric acid and acetate-ammonium buffer exits and the amount of their incorporation into the soil material.

Table 5 - Coefficients of correlation between the amount of trace elements metals, which are determined in hydrochloric and acetate-ammonium buffer extracts and their amount

\begin{tabular}{|c|c|c|c|c|c|c|}
\hline \multirow{2}{*}{} & \multicolumn{3}{|c|}{$\begin{array}{c}\text { buffer ammonium acetate extractor with } \\
\mathrm{pH} \mathrm{4,8}\end{array}$} & \multicolumn{3}{c|}{ hydrochloric acid (HCl) extractor } \\
\cline { 2 - 7 } & 1 month & 3 month & 6 month & 1 month & 3 month & 6 month \\
\hline $\mathrm{Co}$ & $-0,42$ & 0,11 & $-0,22$ & 0,99 & 0,99 & 0,99 \\
\hline $\mathrm{Cu}$ & 0,97 & 0,18 & 0,95 & 0,99 & 0,99 & 0,99 \\
\hline $\mathrm{Mn}$ & 0,88 & 0,75 & 0,82 & 0,93 & 0,98 & 0,99 \\
\hline $\mathrm{Zn}$ & 0,98 & 0,99 & 0,99 & 0,96 & 0,99 & 0,99 \\
\hline
\end{tabular}

According to the correlation analysis, the relationship between the content of trace elements in hydrochloric acid and acetate-ammonium buffer extracts and the amount of their introduction into the soil sample are significant. Which gives us the basis for further work with such a ground material.

A molar solution (volume of 1 liter) with a known content of elements was made during the production of a sample with a known content of trace elements- $25 \mathrm{~kg}$ (the amount of salts of trace elements in the soil sample is 1.5 gross $\mathrm{Cu}, \mathrm{Zn}, \mathrm{Mn}, \mathrm{Co}$ ).

For this experiment, material from an arable layer of soil 0-30 cm in weight of $25 \mathrm{~kg}$ was selected.

The soil material was dried, ground and sifted through a sieve with a diameter of $5 \mathrm{~mm}$. In the prepared soil, of trace elements metals were added as a solution of nitrates and left to dry completely.

After that, the averaging of the crushed SC material was performed.

\section{Conclusions.}

1. Taking into account the intended use of standard samples certified for the mass fraction of trace elements, it is necessary to take into account the extremely high heterogeneity of soil material, usually low mass fraction of trace elements metals, which complicate the establishment of certified values of mass particles of trace elements metals.

2. To increase the mass fraction of trace elements metals in the soil material, the additive method can be used. Using this method allows to determine the concentration of trace elements metals without additional concentration, which reduces the measurement error and enables to work with small stresses.

\section{References}

1. GOST 8.315-97 Standard samples of the composition of substances and materials. Basic provisions. - Effective from 01.07.1999]. M: Mezhgoz. Council for Standardization, Metrology and Certification, 1997. 26 p. [in Russian].

2. Balyuk S.A, Borodina Ya.V., Lazebna M.E., Prokhorova I.A. (2013). The state and prospects of development of means of ensuring traceability of measurement results in soil science and agrochemistry of Ukraine. [Stan i perspektyvy rozvytku zasobiv zabezpechennya prostezhuvanosti rezul'tativ vymiryuvan' u gruntoznavstvi ta ahrokhimiyi Ukrayiny]. Bulletin of Agrarian Science. No. 76. pp. 13-16. [in Ukrainian].

3. DSTU ISO 10390-2001 Quality of soil. Determination of pH . Effective from 01.04.2002. Kyiv: Gosstandart of Ukraine, 2003. 8 p. [in Ukrainian]. 
4. DSTU-4730: 2007 Quality of soil. Determination of granulometric composition by the pipette method for modification AN Kaczynski. Effective as of 01.05.2007. Kyiv: Gosstandart of Ukraine, 2007. 16 p. [in Ukrainian].

5. DSTU 4770.1,2,4-6: 2007 Quality of soil. Determination of the content of mobile compounds of manganese (zinc, iron, cobalt, copper) in soil in a buffer ammonium acetate extract with a $\mathrm{pH}$ of 4.8 by the atomic absorption method. - Effective from 01.01.2007. Kyiv: Gosstandart of Ukraine, 2007. 18 p. [in Ukrainian].

6. Pueyoa M. (2001). A new organic-rich soil reference material for its EDTA- and acetic acidextractable contents of $\mathrm{Cd}, \mathrm{Cr}, \mathrm{Cu}, \mathrm{Ni}, \mathrm{Pb}$ and $\mathrm{Zn}$, following collaboratively tested and harmonized procedures. Journal of Environmental Monitoring. 3, p.238-242. [in England].

7. DSTU-N ISO Guide 35: 2006 Certificate of Standard Specimens. General and statistical principles. Exists in Ukraine from 01.10.2010. Kyiv: Gosstandart of Ukraine, 2010. 28 p. [in Ukrainian].

8. Borodina Ya.V., Nazarenko O.I., Tkachenko LV, Lazebna M.E., Prokhorova I.A. (2011). Experience in creating a standard soil sample. [Dosvid stvorennya standartnoho zrazka gruntu]. Agrochemistry and soil science. 76. P. 10-14. [in Ukrainian].

9. Balyuk S.A., Borodin Ya.V., Lazebna M.E., Tkachenko L.V. (2010). Problems of creation and application of standard soil samples.[Problemy stvorennya ta zastosuvannya standartnykh zrazkiv gruntu]. Bulletin of Agrarian Science. 2. S. 11-16. [in Ukrainian].

10. Borodina Ya.V., Prokhorova I.A., Lazebna M.E. (2012). Rol' standartnykh zrazkiv skladu (ahrokhimichnykh pokaznykiv) gruntu v zabezpechenni prostezhuvanosti rezul'tativ vymiryuvan' [The role of standard samples of the composition (agrochemical indicators) of the soil in ensuring the traceability of the results of measurements]. VIII Mizhnarodna naukovo tekhnichna konferentsiya "Metrolohiya ta vymiryuval'na tekhnika» "Metrolohiya-2012» [Materials of the VIII International Scientific and Technical Conference "Metrology and Metering Technology" "Metrology-2012" Kharkiv, October 9-11]. Kharkiv. pp. 51-53. [in Ukrainian].

11. Borodina Ya. V. (2015). Metrological certification of industry standard soil samples.[ Metrolohichna atestatsiya haluzevykh standartnykh zrazkiv gruntiv] Agrochemistry and Soil Science. No. 82. pp. 6-13. [in Ukrainian]. 